\title{
Coping With Internal Politics in Organizations
}

\author{
George Kichamu,
}

\author{
PHD, Jomo Kenyatta University of Agriculture and Technology,
}

P. O. Box 54525-00200, Nairobi, Kenya.

\begin{abstract}
Every organization has its own unique share of internal politics. A utopian non-political organization is non-existent. When organizations are faced with fierce internal politics, it is a natural tendency for the affected individual(s) and group(s) to fight back or take flight. Internal politics can emerge from individual and (or) group interests. Again, internal politics can either have negative or positive effects on organizations depending on whether they enhance or stultify individuals and organizational objectives. Individual goals motivate one to move up the organization's ladder, while organizational objectives guide entities toward the intended end. Therefore, internal politics which enhance individual and (or) organizational objectives should be promoted whilst those which curtail the same, need to be discouraged. Those in leadership in organizations need to strive to ensure that internal politics only propel the best of the best to leadership positions. Notwithstanding, meticulously playing the right internal politics card could be a competitive edge for those who want an extra-hidden push to where they want to be in organizations. Organizational objectives, however, must always act as the plumb-line to measure authenticity of internal politics in organizations. Hence, authentic internal politics in organizations should indiscriminately offer the necessary support to individuals and (or) groups to actively enhance their objectives.
\end{abstract}

Key words : Individual Behaviour, Group Behaviour, Negative Effects, Positive Effects, Networking Ability, Apparent Sincerity, Social Astuteness, Interpersonal Influence, and Organizational Objectives

\section{Introduction}

Every organization has its own unique share of internal politics. The Webster dictionary defines politics as sagaciousness in devising or promoting a policy within a particular group or organization; shrewdly contrived especially with regard to self-interests or expediency (Neilson, Knott, \& Carhart, 1934). A nonpolitical organization is therefore a myth. Socrates (469-399BC), an ancient Greek philosopher, according to Prabhupada (2014), was politically accused of corrupting the minds of young people in Athens by teaching them the absolute good, however, he chose to die by drinking a poison hemlock instead of compromising his principles. Later, Plato (428-347 BC), a successor of Socrates (as cited in Bauer \& Erdogan, 2015) emphasized that, 'one penalty for refusing to participate in politics is that you end up being governed by inferior leaders'. Essentially, Plato advocated for a society that should be led by a 'philosopher king' (Prabhupada, 2014). Perhaps Plato thought that Socrates' dissenting topoi could have been tolerated if the Ancient Greek's leaders were the top-notch wisest persons. However, political history continues to challenge, not only propositions held by Ancient Greek philosophers, but also any linear argument, that disregards the role of political nuances in leadership. Political literature confirms that politics has been in the human society since time immemorial hence it cannot be expunged from the workplace environment where a majority of people spent most of their time in life.

Precisely, the assertion that internal politics is all over even holds true today. Failing to participate in politics is inadvertently delegating one's innate power to others, perhaps with less experience, skills or knowledge to influence decisions being made around them and for them. Again, sometimes some people say that they detest politics yet their behaviour paradoxically point at politics in action. Because organizations are 
inherently political, and more likely to live longer than individuals working in them, there is an inescapable need for people in organizations to learn how to cope with internal politics. Political knowledge, according to Clements, Boyle, and Proudfoot (2016), can contribute to understanding who we can trust and who we should be wary of. Therefore, individuals in decision-making leadership positions need to ensure that organizations nurture an internal political atmosphere whereby employees can actively and freely contribute to attainment of the set organizational goals. Authentic internal politics in organizations should indiscriminately offer the necessary support to individuals and groups to actively enhance organizational goals. The 'lesser evil' therefore is to treat internal politics as a 'necessary evil' that individuals and groups in organizations should master in order to enhance individual and organizational goals.

\subsection{Statement of the problem}

Despite that a utopian non-political organization is non-existent, different organizations have unique shades of internal politics. Whenever organizations are faced with fierce internal politics, it is a natural tendency for the affected individual(s) and (or) group(s) to fight back or take flight. Hence, internal politics in organizations provide an overt or covert extra-push to individuals and (or) groups toward where they want or wish to be in organizations. Notwithstanding, organizational objectives should act as the plumb-line to measure authenticity of internal politics in organizations. Hence, authentic internal politics should indiscriminately offer the necessary support to all employees in organizations so that they can emerge and actively participate in enhancing individual and (or) organizational objectives

\section{Literature review}

\subsection{Antecedents of Internal Politics in Organizations}

According to Bauer and Erdogan (2015), internal politics in organizations can either be brought about by individual behaviour and (or) group behaviour. I will first look into these two core sources and drivers of internal politics in organizations.

\subsubsection{Individual Political Behaviour}

Personality has an important role in understanding whether one will engage in political behaviour. According to Kilduff and Day (1994), employees with fine political acumen execute their tasks more efficiently; a quality that often influences their performance appraisal ratings. The authors further noted that individual employees with political power volitions often believe that they can influence performance of their organizations. Again, the same authors also established that if an individual has substantially invested in an organization, he/she will probably be expected to display some political behaviour because his/her destiny in life is in the success or downfall of the organization.

Kilduff and Day (1994) argument that when an individual expects to succeed in influencing outcome, he/she is probably to politic is confirmed by Bandura (1996) who notes that, if one believes that the probability of influencing results is nil, one would unlikely spent their resources on a damn lost course. Therefore, internal politics come into play not only when one is optimistic of positive results but ready to employ some implicit powers to achieve individually favourable, but sometimes egoistic results.

\subsubsection{Group Political Behaviour}

This is whereby a team engages in politics not as individuals but as a group. According to James (as cited in Drory \& Vigoda-Gadot, 2010), organizational culture may influence the direction of group politics. This implies that the way an organization operates could influence employees' political nuances. Bauer and Erdogan (2015) observe that when resources begin to dwindle, people could view an organization as more political. Perhaps Charles Darwin's (1809-1882) idea of natural selection should be appreciated more in the management field because sometimes competition amongst employees for limited promotion positions or other preferable rewards in organizations may become a survival-for-the-fittest contest!

Muhammad (2007) notes that once employees are unclear about their job specifications, performance appraisals, promotions, and other human resource (HR) functions, they are likely to perceive their organization as, becoming more political day-in day-out. In addition, Romm and Pliskin (1997) noted that politicking deepens as the subject of concern is presumed important from the affected persons' viewpoint. For example, if the HR department unfairly promotes some younger employees to the expense of senior equally qualified employees, there could emerge two groups (the senior and junior employees) perpetually 
fighting each other. Most likely such competing political groupings could negatively affect organizational objectives.

\subsection{Effects Internal Politics in Organizations}

Turning to the effects of internal politics in organizations would suggest guidelines for engaging in politics in organizations. According to Othman (2008), internal politics in organizations can have negative and (or) positive effects:

\subsubsection{Negative Effects of Politics}

Drory and Vigoda-Gadot (2010) note that politics in organizations could be negative if it re-affirms the selfinterest of an individual at the expense of another and often contradicts organizational objectives. The same authors further observe that some individuals or teams must be beneficiaries of the political wit or else the need to participate in politics will be self-defeating. Othman (2008) notes that negative politics involves convenient and illegal behaviour hence disapproved of because of its ethical dilemmas and foreseeable conflicts. Gotsis and Kortezi (2010) note that negative internal politics is self-serving and above all against organizational objectives. However, some employees engage in self-benefitting political tactics to the expense of others and the entire organization. For example, how would one explain a young witty employee who plays political cards to be promoted while disregarding the loss of jobs by other employees in the organization?

\subsubsection{Positive Effects of Politics}

Othman (2008) observes that internal politics transmits the vital survival energy of organizations. Drory and Vigoda-Gadot (2010) note that positive organizational politics emanates from shared meaning and inspiring teamwork. Positive internal politics act as a symptom of social influence processes that benefits the organization (Gotsis and Kortezi, 2010). For example, if the politicking individuals or teams are competing on the best innovative solutions for an organization, such politics are likely to be regarded as positive since it is geared towards achieving organizational objectives. Hence, positive internal politics in organizations could be a source of competitive advantage for organizations.

\subsection{Political Social Competences}

It is worthwhile we look at core social competencies for individuals and groups engaging in politics in organizations. According to Ferris et al. (as cited in Clements, Boyle, \& Proudfoot, 2016), the politically skilled people are able to use a variety of tactics which enhance their personal and (or) organizational objectives. The authors further classified political social competences into four distinct categories: networking ability, apparent sincerity, social astuteness, and interpersonal influence.

\subsubsection{Networking Ability}

The ability to build a network of strong relationships in organizations is important in navigating a pepper-hot political terrain. In a highly charged political environment, trusted colleagues are important because they can give honest feedback. Hence, leaders need to say what they do and do what they say since insofar as trust is concerned actions speak louder than words. By networking, individuals and (or) groups of people are fostered to create a large pool of individuals with similar interests. Moreover, with the dawn of internet and modern social media sites like the Facebook, Whatsapp, Instagram, Twitter, and so forth, it is easier for people to network, time and space notwithstanding. As such, networking could play a significant role in ensuring that interests of individuals and groups are perpetuated by the large network of friends. Politically inclined individuals, according to Clements, Boyle, and Proudfoot (2016), can shrewdly utilise this quality to establish trust with others.

\subsubsection{Social Astuteness}

The ability to manoeuvre with an aim of influencing individuals and (or) groups in organizations. People are far more likely to do something needed from them if there is something in it for them. Hence, people with social smartness demands that one is in a position to learn people's motivators and engage both heart and mind of an employee. Moreover, social astuteness demands that one is able to identify points of resistance and as a result create buy-ins thus walking at the same tempo with the other person (s). Again, relationships are founded on mutuality and if leaders have strong social allegiances, people may return favour to 
accelerate their career progression opportunities. Social astuteness therefore favours the most witty, sagacious or shrewd individuals and (or) groups. Socially astute people are easily acceptable because, just as it is difficult to predict the outcome of a tossed coin, ordinary people are not very good at deciphering ingenious wit (Clements, Boyle, \& Proudfoot, 2016).

\subsubsection{Apparent Sincerity}

This is the ability to appear sincere when communicating with an aim of convincing others, plausibility of the information notwithstanding (Clements, Boyle, \& Proudfoot, 2016). For the politically shrewd persons, the end justifies the means and therefore they appear authentic in order to be accepted by the target person (s) and (or) group (s). Such individuals master the art of camouflaging so as to buy trust from the target individual (s) and (or) group (s).

\subsubsection{Interpersonal Influence}

Politically shrewd individuals have the ability to reach out to individuals and (or) groups and successfully influence them. The high confidence of the politically shrewd individuals places them at a higher pedestal to persuade others, who are less endowed with such qualities (Clements, Boyle, \& Proudfoot, 2016). Eventually, the way of the politically skilled individuals is often the way to followed by the target group.

\section{Discussion}

There is no doubt that different organizational environments make employees engage in varied political behaviours. Vredenburgh and Shea-VanFossen (2010) identified organizational environment that could make people start politicking in organizations. The work environment could spark some political behaviour from employees. For example, Beugré and Liverpool (as cited in Drory \& Vigoda-Gadot, 2010) note that once employees feel that they are being mistreated, they may adopt self-preserving behaviours. Organizational culture therefore could influence employees' involvement in politics in organizations. Moreover, Nicholson (1997) observes that human beings are inherently predisposed to seek power in whichever place they find themselves, workplaces not exempted. As such, human beings are inherently predisposed to politics!

Since internal politics in organizations cannot be wished away 'coping with internal politics' in organizations could be the only plausible solution to the problem of negative politics. Jean-Baptiste Lamarck, a French biologist, first came up with a coherent theory of evolution which suggested that, "there is a dynamic relationship between species and the environment such that if the external environment changed, an animal's activity patterns would also change to accommodate the new circumstances" (Capra, 1982, p. 58). According to Lamarck (as cited in Capra, 1985), all living things were endowed with a vital force that steered them to evolve toward greater complexity and attain traits that could be imparted to offspring acquired during their lifetimes. For example, Lamarck suggested that the long neck of the giraffe evolved when a short-necked ancestor took to browsing on the leaves of trees instead of on grass (Capra, 1982). However, Lamarck's theory was dismissed since the proposition was not genetically correct.

Notwithstanding the shortfalls in the Lamarckian theory of evolution - the environment in which living beings live significantly determined their adaptive behaviours - there is a lot to learn insofar as the dynamics of internal politics in organizations are concerned. Notably, if an organism fails to adapt itself to the immediate environment, it not only risks itself to death but also risks the whole species to extinction. Similarly, in coping with internal politics in organizations it is important that individuals actively influence the immediate political environment for individual and (or) organizational benefits. Political knowledge can contribute to understanding who we can trust and who we should be wary of (Clements, Boyle, \& Proudfoot, 2016). Therefore, there is a reflexive relationship between individuals and teams in organizations and internal politics. Hence, the most authentic way to cope with internal politics in organizations is to actively and freely get involved in political activities in organizations.

Nevertheless, internal political activities have to be guided by, first and foremost, organizational objectives. Organizational objectives are strategic goals that organizations' management establish to outline expected outcomes and guide employees' efforts (Tech Target, 2007). Fair processes ensure that any eventual emergence of political behaviour will be manageable because there are defined policies and procedures on all human resource management (HRM) functions. Formal decision-making processes encourage a more 
collaborative behaviour instead of an egocentric political behaviour from employees. Such a magnanimous ability to learn and practice authentic internal politics in organizations puts into glare the flipside of internal politics for all to sift and separate the grains of authenticity from the chaff inauthenticity! Nevertheless, authenticity in internal politics may not exclude popularity, resilience, wit, and shrewdness from the equation of individuals and (or) groups focusing and going for what they want in organizations. Notably, authenticity in internal politics should not be misconstrued as insincere or deceitful behaviour. Internal politics therefore is a hallmark of any evolving organization. Therefore, learning the modus operandi of internal politics in organizations could be a covert active way of placing individuals and (or) organizations at a competitive edge. After all, even those viewed as the weakest in a team would wish to be in a position of power one day!

\section{Conclusion}

Internal politics in organizations is a necessary evil that all individuals and (or) groups in organizations need to learn to cope with at all times. Accepting the fact that every organization has multiple forces contributing to internal politics is the first step towards learning to cope with internal politics. Despite the overemphasized flipside of internal politics in organizations, the political game also has a positive quality of sieving candidates and giving the most popular, resilient, witty, and shrewd individual(s) the opportunity to take-over significant positions in organizations. After all, if certain individuals and (or) groups play their political-cards well and internal politics propel them to decision-making leadership positions in organizations, such astuteness could be a manifest of sufficient smartness to lead others. Therefore, learning to cope with internal politics in organizations could be a competitive edge for those who want an extrahidden force to propel them to where they want to be in organizations. Internal politics in organizations therefore should help individuals and (or) groups to learn authentic political skills. As such, the political acumen of those at decision-making positions could be a covert force that propels them and their organizations to the apex, in this flux competitive global market.

\section{References}

[1] Bandura, A. (1996). Self-efficacy: The exercise of control. New York: Worth Publishers.

[2] Bauer, T., \& Erdogan, B. (2015). An introduction to organizational behaviour. Accessed from http://creativecommons.org/lincenses/by-nc-sa/3.0/

[3] Capra, F. (1982). The Turning Point. London: HarperCollins Publishers.

[4] Clements, J. A., Boyle, R., \& Proudfoot, J. G. (2016). Exploring political skill and deception. International Journal of Sociology and Social Policy. 36 (3/4), 13-156. https://doi.org/10.1108/IJSSP-09-2014-0063.

[5] Drory, A. \& Vigoda-Gadot, E. (2010). Organizational politics and human resource management: A typology and the Israeli experience. Human Resource Management Review, 20, 194-202.

[6] Gotsis, G. N. \& Kortezi, Z. (2010). Ethical Considerations in Organizational Politics: Expanding the Perspective. Journal of Business Ethics, 93, 497-517.

[7] Kilduff, M., \& Day, D. (1994). Do chameleons get ahead? The effects of self-monitoring on managerial careers. Academy of Management Journal, 37, 1047-1060.

[8] Muhammad, A. H. (2007). Antecedents of organizational politic perceptions in Kuwait business organizations. Competitiveness Review, 17(14), 234.

[9] Nicholson, N. (1997). Evolutionary psychology: Toward a new view of human nature and organizational society. Human Relations, 50, 1053-1079.

[10] Nielson, W. A., Knott, T. A., \& Carhart, P. W. (1934). Webster's New International Dictionary (2 ${ }^{\text {nd }}$ ed.). USA: The World Syndicate Publishing.

[11] Othman, R. (2008). Organisational Politics: The Role of Justice, Trust and Job Ambiguity. Singapore Management Review, 30(1), 43-53.

[12] Prabhupada, A. C. B. S. (2014). Beyond Illusion and Doubt: A Vedic Perspective on Western Philosophy. Mumbai: The Bhaktivedanta Book Trust.

[13] Romm, C. T. \& Pliskin, N. (1997). Toward a Virtual Politicking Model. Communications of the ACM, 40(11), 95-100.

[14] Tech Target. (2007). What are organizational goals? Accessed on 10/10/2017 from serchio.techtarget.com/ 
[15] Vredenburgh, D. \& Shea Van-Fossen, R. (2010). Human Nature, Organizational Politics and Human Resource Development. Human Resource Development Review, 9(1), 26-47. 